\title{
MICROFINANCE INSTITUTIONS' SUPPORT AND GROWTH OF SMALL AND MEDIUM ENTERPRISES
}

\author{
Abio Morris Geoffrey ${ }^{1}$ and Kalu Onwukwe Emenike ${ }^{2}$ \\ 1,2 Department of Accounting and Finance, College of Economics \\ and Management, Kampala International University Uganda
}

\section{abio@unhcr.org}

\begin{abstract}
This paper investigates the relationship between microfinance institutions' (MFls') support and growth of small and medium size enterprises (SMEs) in Nimule, South Sudan. We use descriptive analysis, Pearson's linear correlation coefficient (PLCC) analysis, and ordinary least square regression analysis to evaluate the responses obtained through questionnaires and interviews. The estimates of descriptive analysis show that majority of the respondents were females (53.7\%); majority (33.7\%) of the respondents had secondary education; and that the majority of respondents (46.3\%) have between 6-8 years experience. Results of the quantitative analysis using PLCC revealed that positive linear relationship exists between loan provision, savings account provision, managerial skills provision and growth of SMEs in Nimule, South Sudan. Similarly, results of the regression analysis indicate that loan provision, savings account provision, and managerial skills provision have positive and significant effect on SMEs growth in Nimule. These findings indicate, amongst others, that MFls support contributes significantly to growth of SMEs in Nimule, South Sudan. The study recommends, among others, that MFls should adopt Microfinance-group model as well as increase provision of non-financial services, such as managerial skills trainings, for SMEs.
\end{abstract}

Keywords: microfinance institutions, SMEs growth, correlation, South Sudan.

JEL $\quad:$ G21; N27

DOI $\quad: 10.24002 /$ kinerja.v22i1.1568

Received : 30/09/2017 Reviewed : 20/01/2018 Final Version : 08/02/2018 


\section{INTRODUCTION}

The importance of microfinance institutions (MFIs) in eradication poverty cannot be over-emphasised. Although systems of credit provision for poor people have a long history, a new wave of microfinance provision has emerged in the past thirty years, inspired by Nobel Peace Prize winner Muhammad Yunus with the aim of reducing poverty by providing small loans to the country's rural poor (Yunus 1999). MFIs does not only provide credit to the poor, but also now spans a myriad of other services including savings, insurance, remittances and non-financial services such as financial literacy training and skills development programmes (Duvendack, Palmer-Jones, Copestake, Hooper, Loke \& Rao, 2011). MFls offer these financial and non-financial services to active poor who are traditionally neglected by conventional banks with a view to lift them out of poverty. MFIs have not only become important in the fight against poverty but are also growing worldwide in number of organisations and clients, and amount of donor funding.

Small and Medium Enterprises (SMEs) are commonly define as registered businesses with less than 250 employees. Mustafa and Saat (2012) refer to SMEs as engine of job creation and growth in emerging markets that are central to the larger equation of development. SMEs can be key part of thriving globally competitive industries, creating the large numbers of jobs needed to reduce poverty. In the right business environment, SMEs can grow into large firms, changing the game locally, carving their niche globally. But even if remaining small or medium-size, they can create significant income opportunities for their workers and generate new tax revenues for government services. They do so by boosting their productivity and sales, and supplying increasingly valuable goods and services. However, throughout the world the efforts of SMEs are inhibited by lack of access to financial services such as deposit and credit facilities and other financial services (Eissa, 2013). According to International Finance Corporation (2011), SMEs are strongly restricted in accessing the capital that they require to grow and expand, with nearly half of SMEs in developing countries rating access to finance as a major constraint. In some African countries like Nigeria, Ghana, Kenya and Uganda the governments are doing what is necessary to raise this sector to its full potential. The governments in these countries do this through and with MFIs. But the reverse is true in South Sudan where the SME sector is never given adequate attention compared to these aforementioned African countries.

Microfinance in post-conflict contexts has come to be seen as a powerful tool to boost local economic development by empowering the poor through increasing their accessibility to investment capital in form of micro credit. The microfinance industry in Sudan is at its infancy stage, and yet the growing interest and demand for financial services by the poor does dramatically outweigh supply (Clement, 2010). Throughout Khartoum rule till the end of civil war in 2005, there were very few commercial banks concentrated in Juba, Wau and Malakal. As a result $90 \%$ of the population in South Sudan were not exposed to banking services. Access to finance was limited to Northern traders operating in Southern Sudan. Majority of the population are without formal financial services. The characteristics of businesses in South Sudan, and low level of financial literacy skills among the population further discourages conventional banks to serve different market segments (Bank of South Sudan, 2013). Yet several recent research findings tend to suggest that MFIs' support in term of credit provision, saving, training on managerial skills and general effects contributes to growth of SMEs. 
There are a good number of empirical studies on the relationship between MFIs' support and growth of SMEs both in developed and developing countries (see for example, Mutua, 2017; Mohamed \& Al-Shaigi, 2017; Prah, 2016; Awuah \& Addaney, 2016; Mulungi \& Kwagala, 2015). While there is scant evidence in the case of South Sudan, there is no study, to the researchers' knowledge, that has examined the relationship between relationship between MFIs' support and growth of SMEs in Nimule. Apart from absence of existing literature, Nimule provides a relatively peaceful environment conducive for SMEs to thrive and for research study. Many other parts of South Sudan have been ravished by civil war, and therefore are not conducive for SMEs and research study because of safety concerns.

The objective of this study therefore, was to evaluate the relationship between MFIs' support and growth of SMEs in Nimule, South Sudan. In specific terms, the study aimed at analysing whether a relationship exist between provision of loan, saving account and managerial skill by MFIs, and growth of SMEs in Nimule, South Sudan. Understanding the relationship between MFls supports and SMEs growth will benefit microfinance institutions and monetary authorities. Microfinance institutions, for example, will identify the appropriate support that is required to enhance SMEs growth. This will reduce loan default from SMEs to meet their obligations in accordance with agreed terms. Monetary authorities will also benefit through the understanding of linkage between MFIs' support and growth of SMEs. This will encourage policy measures to sustain MFIs support thereby boost economic growth. The study will further enrich existing knowledge on relationship between MFIs and SMEs in Africa as well as provide literature for future researchers on related subject. The remainder of this paper organised as follows: Section 2 contains review of empirical literature. Section 3 describes data and methodology. Section 4 presents empirical results and discussions, and section 5 provides conclusions and recommendations.

\section{LITERATURE REVIEW}

Numerous empirical studies have evaluated the relationship between MFIs and SMEs growth. Mutua (2017) conducted a research to investigate the effects of microfinance services on poverty reduction in Makueni County in Kenya using descriptive research design and multivariate regression to determine relative importance of the variables with respect to poverty reductions. The study found that microfinance services (Micro-credit, micro-insurance, saving and training on financial management skills) have positive and significant effects on poverty reduction in Makueni County. Putting emphasis on training (managerial skills), the researcher recommended MFls to undertake several courses on financial management to support their clients to improve their business performance.

Mohamed and Al-Shaigi (2017) examine the impact of microfinance on poverty reduction in Sudan. The study specifically assessed performance and interventions of MFIs in three dimensions; outreach, sustainability, and business development using a case study of Savings and Social Development Bank. The study collected primary data through questionnaire, personal interviews and records. Results of the study show positive impact of MFls on business development in term of increased employment, on other hand moderate impact observed on outreach to poor people and sustainability.

Prah (2016) conducted a research on microfinance credit facilities and the growth of SMEs in the Cape Coast Metropolis of Ghana using descriptive study 
design, and quantitative data analysis with a sample of 357 respondents. The study finding revealed that most of the SMEs in the Cape Coast Metropolis have contracted Microfinance credit facilities, and that there was positive significant difference on growth of the SMEs after receiving the microfinance credit.

Accessing adequate amount of credit is considered to be an important factor in increasing the development and growth of SMEs, and it is also known to boost income, employment level and thereby reduce poverty. Awuah and Addaney (2016) investigated the interactions between MFIs and SMEs in the in the Sunyani Municipality of Kenya by analysing a sample size of 152 respondents. They used survey approach to examine the effects of microfinance services and the products provided by multi credit savings and loan on the performance of SMEs in the area. The research findings revealed that there is positive relationship between MFIs services and the growth of SMEs in the Sunyani Municipality of Kenya. This was evident in the increase in the revenue, profits and asset base of the sampled SMEs after benefiting from SMEs services. They also reported that non-financial services and products such as, managerial training and business advisory services are major contributors in this relationship. The study therefore, recommended intensity of providing these non-financial services for a better performance. In an earlier study in Machakos Kenya, Mbaluka (2013) document that only financing services have helped SMEs attain growth and development. He however argued that minimal levels of provision of financial literacy skill have been offered. He therefore recommended that before granting loans to SME owners, they should first be trained on how to account and manage their businesses, and that MFIs should also plan for seminars and workshops to train the SMEs on financial management, and that MFIs should multiply their efforts on providing managerial skills.

Laetitia, Shukla and Luvanda (2015) investigated the relationship between microfinance and business growth of women SMEs in Kicukiro district, Rwanda using descriptive research design, qualitative and quantitative research approach with a sample size of 275 respondents. The results of Pearson's linear correlation coefficient show that MFIs have positive impacts on the growth of selected SMEs owned by women in Kicukiro in Rwanda. The study also revealed that business performance after loan was fairer compared to before receiving MFIs' loan. The research findings nevertheless noted the challenges of high interest rate. Hence it was recommended that government should intervene by the means of subsidising on the interest rate.

Mulungi and Kwagala (2015) conducted a related study on accessibility of microfinance saving services and its effect on business growth of small scale enterprises in Kampala Uganda by adopting descriptive cross sectional research design and multiple regression with a sample size of 156 respondents. The findings revealed that the level of accessibility of the saving services had a positively significant but weak relationship with the business growth that the selected small scale enterprises attained in terms of sales revenue, profit, business expansion, and product range. They recommended improvement of this relationship by sensitising the MFIs clients through the use of other marketing tool like advertisement.

Nahamya, Max, Omeke, Norman and Moses (2015) sought to establish the impact of microfinance service delivery on the growth of SMEs in Eastern Uganda using multiple regression and logit model. The findings indicate that although the MFIs have performed below a set standard on average due to some industry wide challenges, they have had a significant impact in linking SMEs and the poor to 
sources of credit, and have contributed to the growing business capital and stock accumulation. The researchers recommended that there is need for an institutionalized public-private partnership for creating favourable conditions for the operations of these enterprises. This will reduce on the numerous constraints facing SMEs so as to make the nationals benefit from their overall contribution to poverty reduction. They also recommend designing tailor-made SMEs products through investment in education, setting up an authority or coordination centre for SMEs, and promotion of prudential mechanisms by setting a regulatory and supervisory framework for all Microfinance Institutions.

Clement (2010) investigate the socio-economic impact of microfinance in post conflict situation using SUMI in Juba County South Sudan as a case. The study critically examined what impacts microfinance has on the poor at the household, micro enterprises and the individual levels. The methods used for data collection were mainly semi-structured interviews of 126 active clients associated with SUMI programme, compared to 40 eligible non-clients. These were complemented with direct observations, in addition to, review of relevant literature and related documentation. The analysis of the data collated was done using the inductive analysis approach based on researcher's cautious reasoning and judgment. The results show, amongst others, that SUMI micro enterprise credit played a big role in providing the borrowers with a steadily growing source of income; made valuable contributions to housing improvements and better clothing; access to better health care and education; increased household asset base as compared to non-participants.

From the brief literature review, it is not difficult to observe that MFIs services such as Micro-credit, micro-insurance, saving and provision of managerial skills training, enhances SMEs growth. Again, while numerous empirical literatures exist on the relationship between MFIs services and SMEs growth in emerging and developing countries, such literature is scant for South Sudan.

\section{RESEARCH METHOD}

The study employed primary data. The primary data was obtained through interviews and self-administered questionnaires distributed to owners of SMEs in Nimule South Sudan. The study was restricted to Nimule because of the political crisis in South Sudan. The questionnaire was selected as an instrument to collect the data because it is straight forward and less time consuming for respondents. The questionnaires were structured and were administered through drop and pick later method and the researcher used e-mails and telephone calls to contact the respondents. The Interview was conducted using face-to-face method. This was conducted to bridge the any gap that may be created by questionnaire data.

The target population of the study was the locally 450 registered SMEs managers in Nimule South Sudan. The study covered all the Bomaof Nimule Payam that is to say, OlikwiBoma, Nimule Boma, Rei Boma and JeleiBoma. This population is easily accessible for the researcher. These respondents were considered for the study because of knowledge and skills they possess in relation to the variables under the study. The sample size was determined using the Slovene's formula to determine the minimal sample size. Slovene's formula was estimated as follows:

$n=\frac{N}{1+N(\alpha)^{2}}$

Where; $\mathrm{n}=$ sample size; $\mathrm{N}=$ target population; $\alpha=0.05$ level of significance. 


$$
\begin{aligned}
& n=\frac{450}{1+450(0.05)^{2}} \\
& n=\frac{450}{1+450(0.0025)} \\
& n=\frac{450}{1+1.125} \\
& n=\frac{450}{2.125} \\
& \boldsymbol{n} \cong \mathbf{2 1 2}
\end{aligned}
$$

Therefore the sample size chosen in this study using the Slovene's formula was 212 respondents. Given the nature of the information needed and the locations of the SMEs the research used stratified random sampling techniques to gather data from the respondents. In stratified random sampling, subjects are selected in such a way that the existing sub group in the population are more or less reproduce in the sample. Nimule Payam in this approach was divided into the 4 Boma that is to say Nimule Boma, JeleiBoma, Rei Boma and OliwkiBoma. The researcher listed the population according to the defined strata and determined the required sample size and the appropriate representation in each stratum and the selection was done using random numbers, an appropriate numbers of subjects for each stratum. Stratified random sampling ensures inclusion in the sample, of subgroup, which otherwise would be omitted entirely by other methods because of their small numbers in the population.

The validity of the instrument was established using face and content validity. The Face validity of the instrument was established by cross examination for approval by a research consultant to ensure that the information that was generated were appropriate and consistent before conducting the research. The content validity was conducted using Content Validity Index (CVI). For the instrument to be accepted as valid, the CVI should be 0.7 or above (Amin, 2005). The CVI was estimated as follows:

$$
\begin{aligned}
& C V I=\frac{\text { Number of questions declared valid }}{\text { Total number of questions }} \\
& C V I=\frac{24}{28} \\
& C V I=0.86
\end{aligned}
$$

A CVI value of 0.86 is greater than 0.7 minimum $C V I$ required for a valid instrument. Hence the instrument is valid. Reliability is a measure of the degree to which a research instruments yields consistent results or data after repeated trials Mugenda and Mugenda (2003). To ensure reliability of the research instrument, the study adopted test-retest method. Test-retest reliability, according to Drost (2011), refers to the temporal stability of a test from one measurement session to another. The procedure is to administer the test to group of respondents and then administer the same test to the same respondents at a later date. In this study, nine (9) questionnaires were first given to nine (9) respondents who were not part of the final respondents and then after one week, the same respondents were given the 
same questionnaires. The results from these two sets of responses were then correlated. The coefficient of correlation was 0.87 , which above is above the 0.7 ration required for the instrument to be regarded as reliable.

The Pearson's linear correlation coefficient (PLCC) was adopted to evaluate the relationship between MFIs support and SMEs growth in Nimule South Sudan. The sign (+ or -) indicates the direction of the relationship. The value can range from -1 to +1 , with +1 indicating a perfect positive relationship, 0 indicating no relationship and -1 indicating a perfect negative or reverse relationship. The PLCC $r$ is specified thus:

$$
r=\frac{n \sum(x y)-\left(\sum x\right)\left(\sum y\right)}{\sqrt{\left[n \sum x^{2}-\left(\sum x\right)^{2}\right] \sqrt{\left[n \sum y^{2}-\left(\sum y\right)^{2}\right.}}}
$$

Where, $r$ is the correlation coefficient, $n$ is the number of observations, $x$ and $y$ are dependent and independent variables, in this case microfinance finance support and small and medium scale enterprises. The data analysis was conducted at the $5 \%$ level of significance. Thus if the $p$-value is less than 0.05 , the null hypotheses would be rejected. If, on the other hand, the $p$-value is greater than 0.05 , the null hypotheses would not be rejected.

In addition, multiple regression analysis was conducted using ordinary least square (OLS) method to enhance robustness of finding. The OLS enables the measure of the impact of independent variable(s) (LP, SA, and MSP) on the dependent variable (SMEG). It may be specified as follows:

$\mathrm{SMEG}=\alpha+\beta_{1} \times \mathrm{LP}+\beta_{2} \times \mathrm{SA}+\beta_{3} \times \mathrm{MSP}+\varepsilon$

Where SMEG is small and medium enterprises growth, $L P$ denotes loan provision by SMEs, $S A$ is savings account provision by SMEs, and MSP is managerial skill provision by SMEs, $\beta_{1}, \beta_{2}$ and $\beta_{3}$ are the coefficients of MFIs support services and measures of their effects on SMEs growth, and $\varepsilon$ is the error term that account for other variables not included in the model. The a priori expectation of the slope coefficients are: $\beta_{1}, \beta_{2}$ and $\beta_{3}>0$. Significance of the slope coefficient will be measured using the $p$-value.

\section{DATA ANALYSIS AND DISCUSSION}

\subsection{Analysis of Respondents}

Analysis of respondents is usually conducted to ascertain the percentage of the targeted respondents that actually responded to the questionnaire. From the results presented in Table 1, notice that out 212 targeted respondents who were given questionnaires, only 190 of them filled and returned the questionnaires. This represents a response rate of $90 \%$. This percentage was considered high and good enough to represent the target population, given the busy schedule of the targeted population. The questionnaires returned from the field were assessed and found to be duly completed for use in this study.

In addition, the interview method was adopted to enhance robust analysis and was administered to selected SMEs managers in Nimule, South Sudan. 
Table 1: Response Rate

\begin{tabular}{lll}
\hline Targeted respondents & Actual respondents & $\begin{array}{l}\text { Responses as percentage of } \\
\text { targeted respondents }\end{array}$ \\
\hline 212 & 190 & $90 \%$ \\
\hline
\end{tabular}

Source: Authors' computation

The study presents the demographic profiles of the respondents in Table 2. From the Table 2, observe that majority of the respondents were females with $53.7 \%$, and $46.3 \%$ of the respondents were males. This is an indication that both genders were well involved in SMEs in Nimule, although there are female entrepreneurs than male. Table 4.2 also shows that the finding of the study does not suffer from gender bias.

Notice also, from Table 2, that secondary education is the level of education with the highest response rate. From the table, 33.7\% of the respondents indicated their highest education level as secondary education. This is followed by primary and vocational education, with $19.5 \%$ of the respondents each. Those with university education represented $15.8 \%$ of the respondents, and those without any education represented $11.6 \%$ of the respondents. This is an indication that majority (88.4) of the SMEs operators sampled in this study has formal education.

The study requested the respondents to indicate their years of experience as SME entrepreneur. The estimates from Table 2 established that majority of the respondents have between 6 to 8 years experience, and they account for $46.3 \%$ of the respondents. Those with 2 years and less years of experience account for the minority, with $8.9 \%$. These suggest that majority of those sampled are experienced in SME operation.

Data was collected from the respondent on their type of enterprise. Trade accounted for the highest response rate with $47.9 \%$, followed by small scale farming, with 37.9 respondents. Creative designers accounted for $13.7 \%$ of the respondents whereas others accounted for least response rate with only $0.5 \%$ respondents. These indicate that majority of the respondents are traders.

Table 2: Respondent demographic characteristics

\begin{tabular}{llll}
\hline Variables & Category & Frequency & Percent \\
\hline Gender & Male & 102 & 53.7 \\
& Female & 88 & 46.3 \\
Education level & Total & $\mathbf{1 9 0}$ & $\mathbf{1 0 0 . 0}$ \\
& None & 22 & 11.6 \\
& Primary & 37 & 19.5 \\
& Secondary & 64 & 33.7 \\
& Vocational & 37 & 19.5 \\
& University & 30 & 15.8 \\
Years of Experience & Total & $\mathbf{1 9 0}$ & $\mathbf{1 0 0 . 0}$ \\
& 2 years and below & 17 & 8.9 \\
& 3-5 years & 43 & 22.6 \\
& 6-8years & 88 & 46.3 \\
Type of enterprise & 9years and above & 42 & 22.1 \\
& Total & $\mathbf{1 9 0}$ & $\mathbf{1 0 0 . 0}$ \\
& Trade & 91 & 47.9 \\
& Small scale farming & 72 & 37.9 \\
& Creative design & 26 & 13.7 \\
& Others & 1 & 0.5 \\
& Total & $\mathbf{1 9 0}$ & $\mathbf{1 0 0 . 0}$ \\
\hline
\end{tabular}

Source: Authors' computation 
Table 3: Descriptive statistics on Microfinance Institution's support

\begin{tabular}{|c|c|c|c|c|}
\hline \multicolumn{5}{|c|}{ Panel A: Loan Provision } \\
\hline Indicators & Mean & $\begin{array}{l}\text { Construct } \\
\text { mean }\end{array}$ & S.D. & $\begin{array}{l}\text { Interpre } \\
\text { tation }\end{array}$ \\
\hline $\begin{array}{l}\text { the loan SMEs receive from MFIs are } \\
\text { reasonable for the operation of my business }\end{array}$ & 3.74 & & & \\
\hline $\begin{array}{l}\text { MFIs focus on both group guarantors and } \\
\text { collateral for loan recovery. }\end{array}$ & 3.18 & & & \\
\hline $\begin{array}{l}\text { interest charged by MFIs are relatively } \\
\text { affordable for timely repayment }\end{array}$ & 3.35 & 3.413 & 0.508 & $\begin{array}{l}\text { Very } \\
\text { Good }\end{array}$ \\
\hline $\begin{array}{l}\text { the grace period offered by MFIs are } \\
\text { customer friendly for loan repayment }\end{array}$ & 3.38 & & & \\
\hline \multicolumn{5}{|c|}{ Panel B: Savings Account } \\
\hline $\begin{array}{l}\text { MFIs tend to so much encourage group or } \\
\text { individual saving among small and medium } \\
\text { enterprises }\end{array}$ & 3.49 & & & \\
\hline $\begin{array}{l}\text { MFls tends to facilitate in the process of } \\
\text { saving group formation among small and } \\
\text { medium enterprises }\end{array}$ & 3.34 & 3.403 & 0.515 & $\begin{array}{l}\text { Very } \\
\text { Good }\end{array}$ \\
\hline $\begin{array}{l}\text { the fines or penalties levy on SMEs for none } \\
\text { compliance on savings among small and } \\
\text { medium enterprises are moderate }\end{array}$ & 3.21 & & & \\
\hline $\begin{array}{l}\text { group or individual savings of SMEs are } \\
\text { primarily intended to expand the business }\end{array}$ & 3.58 & & & \\
\hline \multicolumn{5}{|c|}{ Panel C: Managerial Skills Training } \\
\hline $\begin{array}{l}\text { the managerial skills training provided by } \\
\text { MFIs to small and medium enterprise } \\
\text { owners are helpful in running their business }\end{array}$ & 3.63 & & & \\
\hline MFIs normally make follow up on & 3.21 & & & \\
\hline $\begin{array}{l}\text { managerial training skills implementation by } \\
\text { small and medium enterprises }\end{array}$ & & 3.343 & 0.587 & $\begin{array}{l}\text { Very } \\
\text { Good }\end{array}$ \\
\hline $\begin{array}{l}\text { MFIs fully facilitate access to managerial } \\
\text { training skills by small and medium } \\
\text { enterprise owners }\end{array}$ & 3.24 & & & \\
\hline $\begin{array}{l}\text { SMEs usually have the time to attend to the } \\
\text { managerial skills training organised by MFIs }\end{array}$ & 3.38 & & & \\
\hline
\end{tabular}

Source: Authors' computation

Note: S.D. is standard deviation

\subsection{The level of Microfinance Institution's support}

The study sought to establish the level at which respondents agreed or disagreed with the Microfinance Institutions' (MFI's) support to Small and Medium Enterprises' growth in Nimule South Sudan. The researcher concentrated on three constructs of MFl's support, which are loan provision, savings account, and training on managerial skills. From Panel $A$ of Table 3 , majority of the respondents generally strongly agreed that loan provision by MFI's enhances SMEs growth in Nimule South Sudan, with a mean and standard deviation response of 3.41 and 0.50 respectively. They also strongly agreed that interest rate charged by MFIs in Nimule is relatively affordable for timely repayment, and that the grace period offered by MFIs are customer friendly for loan repayment.

From Panel $B$ of Table 3, majority of the respondents generally strongly agreed that provision savings account by MFls boosts SMEs growth in Nimule South Sudan, with a mean and standard deviation response of 3.40 and 0.51 respectively. They also strongly agreed that MFIs tend to encourage group or individual savings among small and medium enterprises and that the MFIs also 
facilitate the process of individuals and group savings formation among SMEs which primarily is intended to expand their business.

From Panel $C$ of Table 3, majority of the respondents generally strongly agreed that managerial skills training provided by MFIs ensures sustainability of SMEs growth in Nimule South Sudan, with a mean and standard deviation response of 3.34 and 0.58 respectively. They also strongly agreed that the managerial skills training provided by MFIs to small and medium enterprise owners are helpful in running their business, and that the MFIs normally make follow up on managerial training skills implementation by small and medium enterprises, which has contributed in their application of the skills acquired from the training.

\subsection{The level of Growth of small and medium enterprises (SMEs)}

This section sought to establish the level at which respondents agreed or disagreed with the Small and Medium Enterprises' growth in Nimule South Sudan resulting from Microfinance Institutions' (MFI's) support. The researcher adopted three proxies of SMEs' growth, which are increase in productivity, employment creation, and sales growth. From Panel $A$ of Table 4, majority of the respondents generally strongly agreed that MFIs support has increased their profitability in Nimule South Sudan. This is evident in the mean response of 3.41 and standard deviation 0.47 . Thus imply that MFIs support results in increased profit of SMEs. The respondents also strongly agreed that through the supports of MFls they are able to fully train their employee(s) to run daily operation as they focus on key business activities, and to minimize wastage and spoilage of stock. More so, the respondents agree that MFIs support have contributed to cost reduction in the running of their businesses as well as enhancing customer satisfaction.

As shown in Panel $B$ of Table 4, the respondents strongly agreed that provision savings account by MFIs boosts SMEs growth in Nimule South Sudan, with mean response of 3.33 and standard deviation and 0.52 . They strongly agreed that the SMEs have become an important actor in employment creation among the local communities in Nimule South Sudan, and that through the effort of MFIs, they are able to provide social responsibilities to their host communities.

The results presented in Panel $C$ of Table 4 show that the respondents generally strongly agreed that MFls support has enable them to grow their sales in Nimule South Sudan, with a mean response and standard deviation of 3.34 and 0.58 respectively. They strongly agreed that the MFIs trainings they received have contributed to improved marketing skills like pricing their products appropriately, and have contributed to customer creation skills. The respondents also agreed that the supports of MFIs have contributed to increased rate of stock turnover in their business, which has in turn increased the level of their turnover.

The informants generally believe that MFIs support has enhanced the SMEs growth in Nimule South Sudan. 
Table 4. Descriptive statistics on SMEs Growth

Panel A: Increase Profitability

\begin{tabular}{|c|c|c|c|c|}
\hline Indicators & Mean & $\begin{array}{l}\text { Construct } \\
\text { mean }\end{array}$ & S.D. & $\begin{array}{l}\text { Interpre } \\
\text { tation }\end{array}$ \\
\hline $\begin{array}{l}\text { through the supports of MFIs I am able to fully } \\
\text { train my employee(s) to run daily operation as } \\
\text { I focus on key business activities }\end{array}$ & 3.68 & & & \\
\hline $\begin{array}{l}\text { through the support of MFIs to my business it } \\
\text { has made it possible for to me to make my }\end{array}$ & 3.48 & & & $\begin{array}{l}\text { Very } \\
\text { Good }\end{array}$ \\
\hline $\begin{array}{l}\text { customers go satisfied } \\
\text { MFIs have contributed to cost reduction in the } \\
\text { way I run my business as SME owner }\end{array}$ & 3.22 & 3.411 & 0.476 & \\
\hline $\begin{array}{l}\text { the supports of MFIs have made it possible for } \\
\text { me as SME owner to minimize wastage and } \\
\text { spoilage of stock }\end{array}$ & 3.27 & & & \\
\hline $\begin{array}{l}\text { Panel B: Employment Creation } \\
\text { my business SME has become an important } \\
\text { actor in employment creation among the local } \\
\text { community }\end{array}$ & 3.70 & & & \\
\hline $\begin{array}{l}\text { my small and medium enterprise has } \\
\text { contributed to improved standard of living for }\end{array}$ & 3.48 & & & $\begin{array}{l}\text { Very } \\
\text { Good }\end{array}$ \\
\hline $\begin{array}{l}\text { me as SME owner } \\
\text { my small and medium enterprise has } \\
\text { contributed to increase level of income for me } \\
\text { as SME owner and others }\end{array}$ & 3.25 & 3.473 & 0.463 & \\
\hline $\begin{array}{l}\text { as SME owner through the effort of MFIs in my } \\
\text { business i am able to meet my social } \\
\text { responsibilities } \\
\text { Panel C: Sales Growth }\end{array}$ & 3.46 & & & \\
\hline $\begin{array}{l}\text { MFIs training have contributed to improved } \\
\text { marketing skills like pricing for my products for } \\
\text { me as SMEs owner }\end{array}$ & 3.47 & & & \\
\hline $\begin{array}{l}\text { MFIs have contributed to customer creation } \\
\text { skills in the way I run my business as small }\end{array}$ & 3.36 & & & Very \\
\hline and medium enterprise & & 3.331 & 0.525 & Good \\
\hline $\begin{array}{l}\text { MFIs have contributed to improved level of my } \\
\text { business revenue as small and medium } \\
\text { enterprise }\end{array}$ & 3.32 & & & \\
\hline $\begin{array}{l}\text { the supports of MFIs have contributed to } \\
\text { increased rate of stock turnover in my business } \\
\text { as SME }\end{array}$ & 3.18 & & & \\
\hline
\end{tabular}

Source: Authors' computation

\subsection{MFls support and growth of SMEs in Nimule, South Sudan}

\subsubsection{Loan provision by MFls and growth of SMEs}

This section reports the results of the Pearson's linear correlation coefficient (PLCC) conducted to determine the relationship between loan provision by MFIs and growth of SMEs in Nimule, South Sudan. Observe from Table 5 that a moderate positive linear relationship exists between loan provision by MFIs and growth of SMEs in Nimule, South Sudan. This is evident in the correlation coefficient of 0.489 . This result suggests that an increase in loan provision by MFIs is likely to increase SMEs growth in Nimule, South Sudan.

This finding is statistically significant since the $p$-value $(0.000)$ of the PLCC is less than the significance level (0.05). Hence, there is significant positive relationship between loan provision by MFIs and SMEs growth in Nimule South Sudan. This finding agrees with the conclusion of Nahamya, et al ( 2013) that MFIs 
have a significant impact in linking SMEs and the poor to sources of credit and contributed to their growth in terms of growth of business capital and stock accumulation. The finding is also in line with the findings of Awuah and Addaney (2016) who maintained that micro-credit has a significant positive relationship with SMEs growth Sunyani Municipality of Kenya.

Table 5: Relationship between loan provision and growth of SMEs in Nimule South Sudan

\begin{tabular}{llll}
\hline & & Loanprovision & SMEs Growth \\
\hline \multirow{3}{*}{ Loan provision } & Pearson Correlation & 1 & $.489^{* *}$ \\
& Sig. (2-tailed) & & .000 \\
& $N$ & 190 & 190 \\
SMEs Growth & Pearson Correlation & $.489^{* *}$ & 1 \\
& Sig. (2-tailed) & .000 & 190 \\
& $\mathrm{~N}$ & 190 &
\end{tabular}

${ }^{\star \star}$. Correlation is significant at the 0.01 level (2-tailed).

\subsubsection{Savings account provision by MFIs and growth of SMEs}

This section reports the results of the PLCC conducted to establish the relationship between provision of savings account by MFIs and growth of SMEs in Nimule, South Sudan. Notice from Table 6 that a moderate positive linear relationship exists between savings account provision by MFIs and growth of SMEs in Nimule, South Sudan. This is evident in the calculated correlation coefficient of 0.452. This result suggests that an increasing savings account in MFIs is likely to increase SMEs growth in Nimule, South Sudan.

This finding is also significant the $p$-value (0.000) of the PLCC of the relationship between provision of savings account by MFIs and growth of SMEs in Nimule, South Sudan is less than the significance level (0.05). For this reason, there is significant positive linear relationship between savings account provision by MFIs and SMEs growth in Nimule South Sudan. This finding agrees with the findings of Mulungi and Kwagala (2015) which maintains that accessibility of the saving services have a positively significant but weak relationship with the business growth in Kampala Uganda.

Table 6: Relationship between savings account and growth of SMEs in Nimule South Sudan

\begin{tabular}{llll}
\hline & & Saving account & SMEs Growth \\
\hline \multirow{3}{*}{ Saving account } & Pearson Correlation & 1 & $.452^{* *}$ \\
& Sig. (2-tailed) & & .000 \\
& $N$ & 190 & 190 \\
SMEs Growth & Pearson Correlation & $.452^{* *}$ & 1 \\
& Sig. (2-tailed) & .000 & \\
& $\mathrm{~N}$ & 190 & 190 \\
\hline
\end{tabular}

${ }^{* *}$. Correlation is significant at the 0.01 level (2-tailed).

\subsubsection{Managerial skills provision by MFIs and growth of SMEs}

This section presents the results of the Pearson's linear correlation coefficient (PLCC) conducted to evaluate the relationship between managerial skills provision by MFIs and growth of SMEs in Nimule, South Sudan. We can see from Table 7 that a weak positive linear relationship exists between managerial skills provision by MFIs and growth of SMEs in Nimule, South Sudan. This is evident in 
the computed correlation coefficient of 0.371 . This result suggests that an increase in provision managerial skills by MFIs is likely to increase SMEs growth in Nimule, South Sudan.

This finding is equally significant since the $p$-value (0.000) of the PLCC is less than the significance level (0.05). Hence, there is significant positive linear relationship between managerial skill provision by MFIs and SMEs growth in Nimule South Sudan. This finding is in line with the findings of Mungai (2015) which shows a positive relationship between provision of training to SMEs owner and the growth of their business. It is in tune with the findings of Mutua (2017), and Awuah and Addeney (2016) who show that non-financial support rendered to SMEs result in a greater scale of growth for the SMEs, in their respective locations of research.

Table 7. Relationship between managerial skills and growth of SMEs in Nimule South Sudan

\begin{tabular}{llll}
\hline & & Managerial skills & SMEs Growth \\
\hline \multirow{3}{*}{ Managerial skills } & Pearson Correlation & 1 & $.371^{* *}$ \\
& Sig. (2-tailed) & & .000 \\
& $N$ & 190 & 190 \\
SMEs Growth & Pearson Correlation & $.371^{* *}$ & 1 \\
& Sig. (2-tailed) & .000 & 190 \\
\hline
\end{tabular}

${ }^{* *}$. Correlation is significant at the 0.01 level (2-tailed).

\subsubsection{Effect of MFls support services on the growth}

The results of the multiple regression OLS model specified in equation (4) are presented in Table 8 below. Notice from the table that the coefficients of loan provision (.39), savings account provision (.35), and managerial skills provision (.25) have positive and significant effect on SMEs growth in Nimule. The significance of the microfinance support services coefficients is evident in their $p$-values, which are less than 0.05 . This implies that the microfinance support services contribute positively to the growth of SMEs growth in Nimule South Sudan. The value of the coefficient of determination $\left(R^{2}\right)$ stood at 0.54 . This indicates that $54 \%$ of the total variation in SMEs growth is accounted for by the MFIs support services. The Durbin-Watson coefficient (1.68) suggests that there is absence of first order serial correlation in the residuals with $90 \%$ confidence.

The results of the regression model agree with those of correlation analysis, which shows evidence of positive and significant relationship between loan provision, savings account provision, and managerial skills provision. A major economic implication of these findings is that any factor that enhances provision of microfinance services will boost growth of SMEs in South Sudan. 
Table 8. Effect of MFIs services on growth of SMEs in Nimule South Sudan Model Summary

\begin{tabular}{|c|c|c|c|c|c|}
\hline Model & $\mathrm{R}$ & R Square & Adjusted R Square & $\begin{array}{l}\text { Std. Error of the } \\
\text { Estimate }\end{array}$ & Durbin-Watson \\
\hline 1 & $.539^{a}$ & .291 & .279 & .34574 & 1.683 \\
\hline
\end{tabular}

a. Predictors: (Constant), managerialskills, savingaccount, loanprovision

b. Dependent Variable: SMEsGrrowth

ANOVA $^{\mathrm{a}}$

\begin{tabular}{rlrrrrr}
\hline Model & & Sum of Squares & Df & Mean Square & F & Sig. \\
\hline \multirow{4}{*}{1} & Regression & 9.111 & 3 & 3.037 & 25.408 & $.000^{\mathrm{b}}$ \\
& Residual & 22.234 & 186 & .120 & & \\
& Total & 31.345 & 189 & & & \\
\hline
\end{tabular}

a. Dependent Variable: SMEsGrrowth

b. Predictors: (Constant), managerialskills, savingaccount, loanprovision

Coefficients $^{a}$

\begin{tabular}{llrrrrr}
\hline Model & & Unstandardized Coefficients & \multicolumn{2}{c}{$\begin{array}{c}\text { Standardized } \\
\text { Coefficients } \\
\text { Beta }\end{array}$} & t & Sig. \\
& & B & Std. Error & Beta & \\
\hline \multirow{3}{*}{1} & (Constant) & 1.716 & .196 & & 8.758 & .000 \\
& Loanprovision & .392 & .051 & .489 & 7.688 & .000 \\
& Savingaccount & .357 & .051 & .452 & 6.947 & .000 \\
& Managerialskills & .257 & .047 & .371 & 5.484 & .000 \\
\hline
\end{tabular}

a. Dependent Variable: SMEsGrrowth

\subsection{Interview Response of MFIs Support and Growth of SMEs}

Majority of the interviewees have college level education, and have been receiving support from MFIs for more than five years. They agree that MFIs have provided services such as provision of loans, savings accounts and managerial skills training services, and that these services have positive effects in growing their businesses in Nimule South Sudan. These opinions agree in totality with the empirical evidence documented in Section 4.1 to 4.4 of this section.

\section{CONCLUSION}

This study evaluated the relationship between Microfinance Institutions (MFIs) support and growth of Small and Medium Enterprises (SMEs) in Nimule South Sudan by analysing the responses obtained through questionnaires and interviews using descriptive analysis, Pearson's linear correlation coefficient (PLCC), and regression analysis. From analysis of respondents, the percentage of targeted respondents that actually responded to the questionnaire was $90 \%$. From the preliminary analysis conducted in the study, majority of respondents in this study have the following attributes, (a) secondary school level education, (b) are females, (c) traders, and (d) have between 6 to 8 years experience. The results of the Pearson's linear correlation coefficient (PLCC) conducted to determine the relationship between MFIs support and growth of SMEs in Nimule, South Sudan establish that MFIs support (Ioan provision, savings account provision, and managerial skills provision) have positive linear relationship with SMEs growth in 
Nimule, South Sudan. Similarly results of the regression analysis indicate that loan provision, savings account provision, and managerial skills provision have positive and significant effect on SMEs growth in Nimule. We therefore conclude that loan provision, savings account provision, and managerial skills provision are strong variables in determining SMEs growth in South Sudan. Hence, Microfinance Institutions supports have enhanced growth of Small and Medium Enterprises in Nimule South Sudan.

Consequently, we recommend that MFIs should encourage SMEs growth by advancing soft loans to entrepreneurs in South Sudan. In order to reduce repayment default, MFIs can research into very profitable business lines and offer credit to clients who have the capacity to exploit such business lines. SMEs should be encouraged also to adopt group financing so as to avert loan defaulting. To overcome the challenges of collateral security required by MFIs to advance loan to SMEs, MFIs, we recommend that MFIs adopt Microfinance-Group model, which involve collective responsibility and security afforded by the formation of a group entrepreneurs. The collective coming together of individual members is used for a number of purposes: educating and awareness building, collective bargaining power, peer pressure etc We also recommend that MFIs should increase provisions of non-financial services for SMEs such as managerial skills to enhance entrepreneurial capability of SMEs.

\section{Acknowledgement}

We would like to thank Dwitya Aribawa, the Editor in Chief of KINERJA (Journal of Business and Economics), as well as the anonymous referees who graciously provided us with feedback on this manuscript. Their comments provided us with valuable suggestions that helped shape this paper.

\section{REFERENCES}

Amin, E.M., 2005. Social science research: Conception, methodology and analysis. Kampala: Makerere University of Printery

Awuah, S. B. and Addaney, M., 2016. The interactions between microfinance institutions and small and medium scale enterprises in the Sunyani municipality of Ghana. Asian Development Policy Review, 4(2). pp. 51-64.

Bank of South Sudan., 2013. Financial sector. South Sudan investment conference.

Clement, L. K., 2010. Socio-economic impact of microfinance in post conflict situation: A case of SUMI in Juba County Sudan. Unpublished Master Thesis submitted to University of Khartoum.

Drost, E. A., 2011. Validity and reliability in social science research. Education. Research and Perspective. 38(1), pp.105-123.

Duvendack, M., Palmer-Jones, R., Copestake, J.G., Hooper, L., Loke, Y. \& Rao, N., 2011. What is the evidence of the impact of microfinance on the well-being of poor people? EPPI-Centre, Social Science Research Unit, Institute of Education, University of London, August.

Eissa, G. S., 2013. Microcredit as a strategy for poverty reduction: A case study of the Sudan. Journal of Modern Accounting and Auditing, 9(4), pp. 557-570. 
International Finance Corporation, 2011. South Sudan. Telling Our Story, 5(1), pp.12-13.

Laetitia, M., Shukla, A. and Luvanda, A., 2015. Microfinance and business growth of women small and medium enterprises in Rwanda: A case of selected women small and medium enterprises in Kicukiro district. European Journal of Accounting, Auditing and Finance Research, 3(11), pp. 26-39.

Mohamed, H. A. and Al-Shaigi, R. S. M., 2017. The role of microfinance in reducing poverty rate in Sudan: A case study of saving \& social development bank. International Journal of Science, Environment and Technology, 6(2), pp.1460 $-1475$.

Mugenda, O.M. and Mugenda, A.G., 2003. Research methods: Quantitative and qualitative approaches. Nairobi Kenya: African Centre for Technology Studies

Mulungi, R. and Kwagala, M., 2015. Accessibility of microfinance savings services and its effect on business growth of small enterprises in Uganda: A case of pride microfinance branches and their small scale enterprise clients in Kampala. Research journali's journal of management, 3(5), pp. 1-20.

Mungai, D. W., 2015. The effect of micro-finance services on the growth of small and medium enterprises in Kajiado County Nairobi. Unpublished Dissertation, School of Business, University of Nairobi

Mustafa, A. K.A. and Saat, M. M., 2012. Assessing performance and intervention of microfinance institutions: a case study in Sudan. Interdisciplinary Journal of Contemporary Research in Business, 4(5), pp. 401-418

Mutua, F.N., 2017. Effect of microfinance services on poverty reduction in Makueni County. Unpublished Master of Business Administration Thesis, South Eastern Kenya University.

Nahamya, K. W., Max, A., Omeke, M., Norman, T. and Moses, N., 2015. The impact of microfinance service delivery on the growth of SMEs in Uganda. International Journal of Economics, Commerce and Management, III(5), pp. 229-237.

Prah, S., 2016. Microfinance credit facilities and the growth of the small and medium scale enterprises in Cape Coast Metropolis of Ghana. International Journal of Economics, Commerce and Management, IV(12), pp. 719-745.

Yunus, M., 1999. Banker to the poor: microlending and the battle against world poverty. New York: Public Affairs. 